\title{
Price and non-price decision making factors for groundnut production in Karnataka: An evidence from Nerlove's supply response approach
}

\author{
S.M. Jainuddin*, Seema ${ }^{1}$, K. Suhasini ${ }^{2}$ and T. Lavanya ${ }^{2}$ \\ Department of Agricultural Economics, College of Agriculture (UAS), Kalaburagi (Karnataka) India \\ (Email:smjainu@gmail.com)
}

\begin{abstract}
The study was conducted with objectives to assess the decision making factors in allocation of area for groundnut production in Karnataka. The secondary data on price and non-price variables were collected from the period 1975-76 to 2015-16. The study concluded that the lagged area, lagged production and lagged yield had exerted significant influence on current year's area, production and yield of the crop across all the period. The study showed that the co-efficient of non-price factors such as rainfall or irrigation was significant which is more important and complementary to price factors for decision making in allocation of land for groundnut production in the state. The study suggested that, attention should be given to expansion of irrigation facility and developing the suitable HYV in groundnut through suitable policy and programmes in the state which may encourage farmers to achieve stable yields and incomes. The government agenises like SAU; Dept of Agriculture, GOK; Extension units, KOF etc., have to arrange for the buyback of groundnut oilseed with processors or oil millers that could benefit the farmers and in turn farmers will expand the area under oilseeds crops in general and groundnut crop in particular in the state.
\end{abstract}

Key Words : Supply response, Price factors, Non-price factors, Oilseeds, Groundnut

JEL Codes: C32, Q10, Q18, R15

View Point Article : Jainuddin, S.M., Seema, Suhasini, K. and Lavanya, T. (2021). Price and non-price decision making factors for groundnut production in Karnataka: An evidence from Nerlove's supply response approach. Internat. J. agric. Sci., 17 (1) : 1-8, DOI:10.15740/HAS/ IJAS/17.1/1-8. Copyright@2021: Hind Agri-Horticultural Society.

Article History : Received : 21.09.2020; Revised : 02.11.2020; Accepted : 01.12.2020

\footnotetext{
* Author for correspondence :

${ }^{1}$ College of Agriculture, Professor Jayashankar Telangana State Agricultural University, Hyderabad (Telangana) India

${ }^{2}$ Department of Agricultural Economics, Professor Jayashankar Telangana State Agricultural University, Hyderabad (Telangana) India
} 